\title{
Circadian rhythmicity in the location of zooxanthellae of the scyphomedusa Linuche unguiculata
}

\author{
John H. Costello*, Patricia M. Kremer \\ Department of Biological Sciences, University of Southern California, Los Angeles, California 90089-0371, USA
}

\begin{abstract}
The scyphomedusa Linuche unguiculata possesses patches of zooxanthellae which expand and contract with circadian regularity. Zooxanthellae are enclosed by vacuole-like membranes and appear to be located within mesogleal cells. Constant light conditions cause damping of the expansion-contraction rhythm within 24 to $48 \mathrm{~h}$, while rhythms persist in constant dark conditions for at least 72 to $96 \mathrm{~h}$. The timing of maximum zooxanthellae patch expansion coincides witr. peak zooxanthellae photosynthetic capacity, suggesting that the expansion-contraction rhythm may aid in the mutual nutrition of both host and symbiont.
\end{abstract}

\section{INTRODUCTION}

Diel expansion and contraction rhythms of tissues containing symbiotic dinoflagellates (zooxanthellae) are common among coral reef cnidarians (Sebens \& DeRiemer 1977). Tissues containing zooxanthellae generally expand during the day and contract at night. These shifts are hypothesized to favor photosynthesis by zooxanthellae, thus benefiting both host and symbiont (Vareschi \& Fricke 1986). Previous expansioncontraction rhythms have been classified as simple stimulus-response behaviors cued to ambient light intensity (Gladfelter 1975, Sebens \& DeRiemer 1977. Fricke \& Vareschi 1982) with no endogenous rhythm component.

Linuche unguiculata, a tropical scyphomedusa, possesses patches of zooxanthellae as well as subumbral pouches, which expand and contract markedly on a diel basis. The experiments reported in this paper were designed to answer 2 questions in regard to the $L$. unguiculata zooxanthellae patch expansion-contraction rhythm: (1) Is the expansion-contraction rhythm cued directly by light or is the rhythm endogenous? (2) What is the mechanism of zooxanthellae movement: are the zooxanthellae extracellular and motile, or are

\footnotetext{
- Present address: Department of Biology, Providence College, Providence, Rhode Island 02918-0001, USA
}

they intracellular and part of an organized tissue movement?

\section{METHODS}

Linuche unguiculata medusae in all experiments were collected from waters near the Exuma Cays, Bahamas. Specimens for light and electron microscopy were fixed in the field while medusae used in rhythm experiments were transported to the University of Southern California in Los Angeles, USA.

Preparation of medusae for microscopy entailed the following procedure: specimens were placed in $2 \%$ glutaraldehyde in filtered seawater and stored in the dark at $5{ }^{\circ} \mathrm{C}$. Light and transmission electron microscopy specimens were later postfixed in $2 \%$ osmium tetroxide in $0.2 \mathrm{M}$ cacodylate buffer, dehydrated in ethanol and embedded in Epon plastic resin. Thick sections for light microscopy were treated with methylene blue while thin sections cut from the same blocks were stained with uranyl acetate. Light micrographs were taken with an Olympus ight micrography setup. Transmission electron photographs were taken on a Jeol $11 \mathrm{cxII}$ electron microscope at $80 \mathrm{kV}$. Specimens prepared for scanning electron microscopy (SEM) were not transferred into osmium tetroxide but were cryofractured, critical point dried and coated according to the methods of Muscatine et al. (1986). SEM photo- 


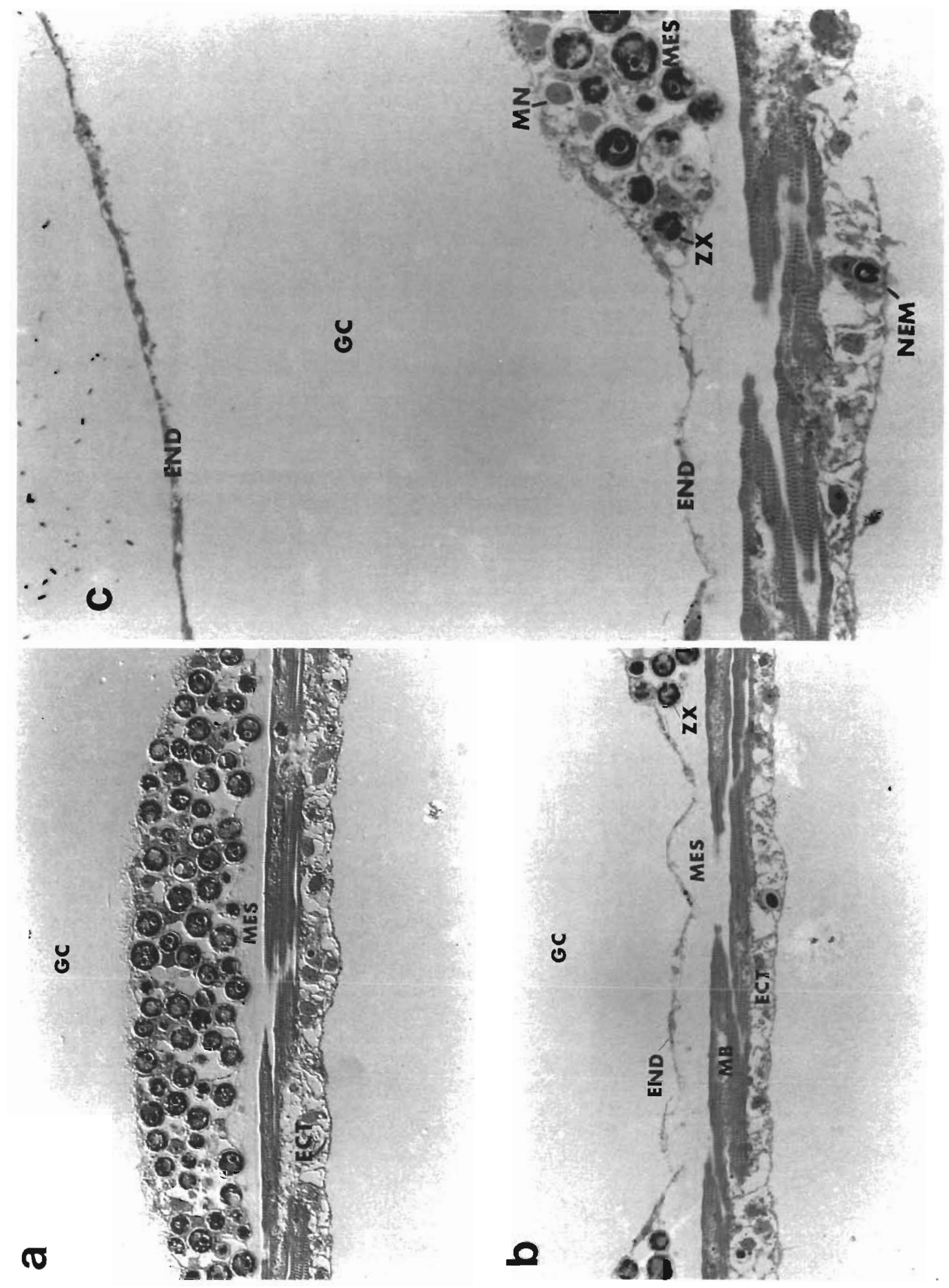


Fig. 2. Linuche unguiculata. TEM showing animal cell nucleus (NU) among several zooxanthellae $(Z X)$ in mesoglea, $\times 5000$

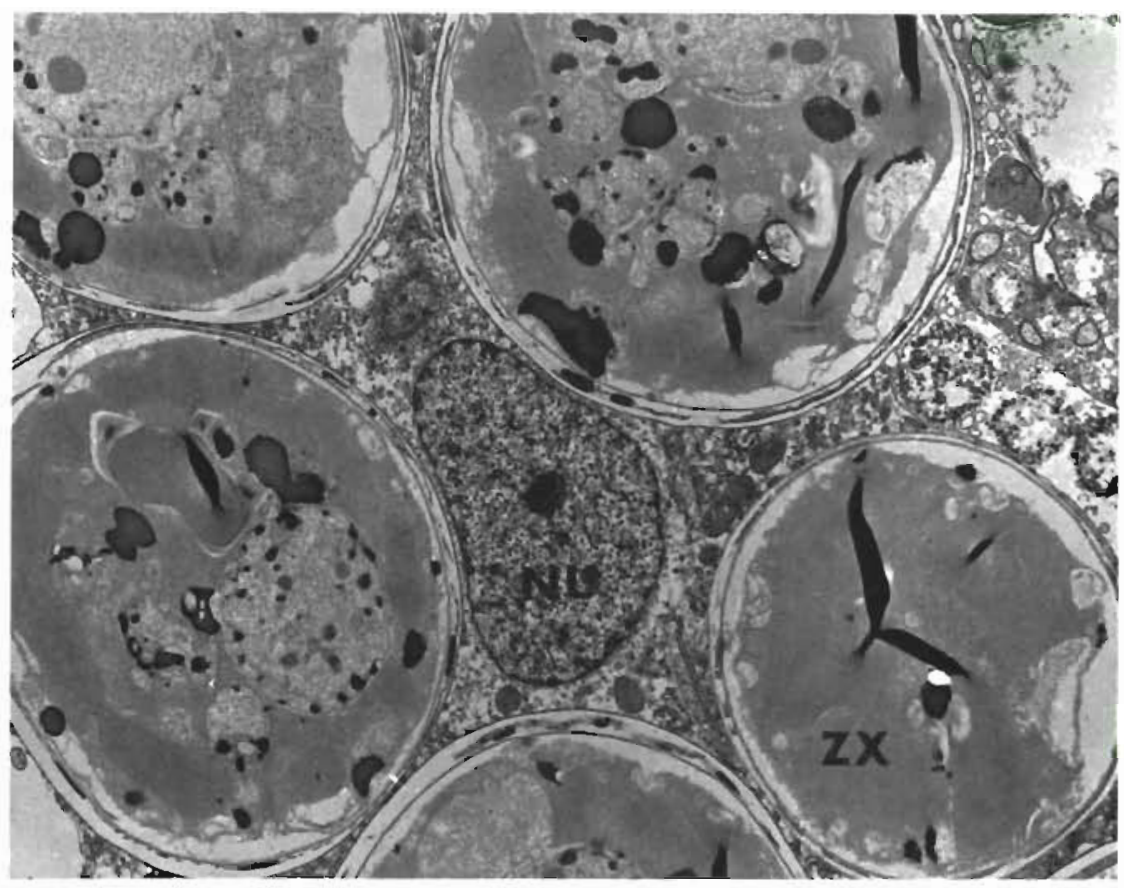

graphs were taken using a Cambridge S4-10 SEM.

Endogenous control of zooxanthellae patch expansion-contraction rhythmicity was tested by subjecting medusae to several light regimes (12 h light: $12 \mathrm{~h}$ dark, constant light of 2 intensities [ 5 and $300 \mu \mathrm{E} \mathrm{m}^{-2} \mathrm{~s}^{-1}$ ] and constant dark) while recording patch size variations with a Zeiss dissecting microscope adapted for photomicroscopy. Three medusae were exposed to each light treatment; photographs of each medusa were taken every $4 \mathrm{~h}$ for $5 \mathrm{~d}$. A GTCO digitizing tablet was used to scan the outline of zooxanthellae patches on the photographs. Data was converted to areas using software installed on an IBM personal computer interfaced to the digitizing tablet.

\section{RESULTS}

\section{Location of zooxanthellae within host tissues}

Coccoid shaped zooxanthellae were located in the mesoglea between the endoderm and ectoderm (Fig. 1). During the contracted phase, the zooxanthellae were condensed and formed a thick layer, 4 to 5 cells deep (Figs. $1 \mathrm{a}$ and $3 \mathrm{c}, \mathrm{d}$ ). Zooxanthellae patches were separated by areas with few or no zooxanthellae in the mesoglea (Figs. $1 \mathrm{~b}$ and $3 \mathrm{c}$, d). The mesoglea contained nuclei (Fig 1c), although whole mesogleal cells with cell membranes were not observed. Zooxanthellae were encapsulated by several vacuole-like membranes (Fig. 2). Zooxanthellae dispersed during the expanded patch phase and formed a layer 1 to 2 cells thick in the mesoglea (Fig. 3a,b).

\section{Patch size variation}

Patches of zooxanthellae within Linuche unguiculata expand during the day and contract at night (Fig. 4) in a predictable pattern. Within 1 medusa, individual zooxanthellae patches expanded and contracted with similar patterns (Fig. 5). Therefore, only measurements of the central patch in best focus are reported here. Measurements of patch area throughout a $12 \mathrm{~h}$ light: dark cycle indicate that initiation of patch area expansion actually preceeded the onset of light and contraction preceeded the onset of darkness (Fig. 6a). These patterns suggested that changes in patch area followed endogenous control rather than a simple light or darkness stimulus. Experiments utilizing medusae maintained on different light regimes confirmed this. Medusae maintained under conditions of either con-

Fig. 1. Linuche unguiculata. Light micrograph of cross section through the lower bell of showing ectoderm (ECT), endoderm (END), mesoglea (MES), zooxanthellae (ZX), muscle bands (MB), gut cavity (GC), nematocyst (NEM) and mesogleal cell nucleus (MN). Ectodermal cells of the lower bell area contain numerous muscle fibers which form the circular muscle bands used in bell contraction. (a) Zooxanthellae patch during contraction; (b) area between zooxanthellae patches during the contracted phase; (c) section showing relationship of zooxanthellae to both layers of endoderm and gut cavity. $(a, b) \times 450 ;(c) \times 650$ 
stant high $\left(300 \mu \mathrm{E} \mathrm{m}^{-2} \mathrm{~s}^{-1}\right.$, Fig. 6b) or low $\left(5, \mathrm{E} \mathrm{m}^{-2} \mathrm{~s}^{-1}\right.$, Fig. 6c) light generally exhibited a residual cycle of normal expansion-contraction followed by a damping out of the rhythm. Within 24 to $48 \mathrm{~h}$, the rhythm became less coherent and patches of zooxanthellae assumed a contracted form and ceased expanding (Fig. 6b, c). Medusae maintained in darkness (Figs. 6d and 7) continued to show rhythmic variation in patch area, although the pattern became less clear after the 3 rd day of the experiment. Medusae held in constant darkness tended to have longer cycle lengths $(>24 \mathrm{~h}$ ) and after several days these medusae were out of phase with those held on a light: dark cycle (Fig. 7).

Controls were designed to determine whether exposure to light during photography (less than 1 min duration) affected the rhythm for constant dark treatment medusae. Beginning on the 3rd experimental day, 1 control medusa was removed from constant darkness and photographed during each sampling period. Therefore, each constant dark control data point in Fig. 8 represents an individual medusa maintained in uninterrupted darkness until the medusa was photographed. The timing of the rhythm for these medusae was similar to others held in the dark, but the amplitude of the
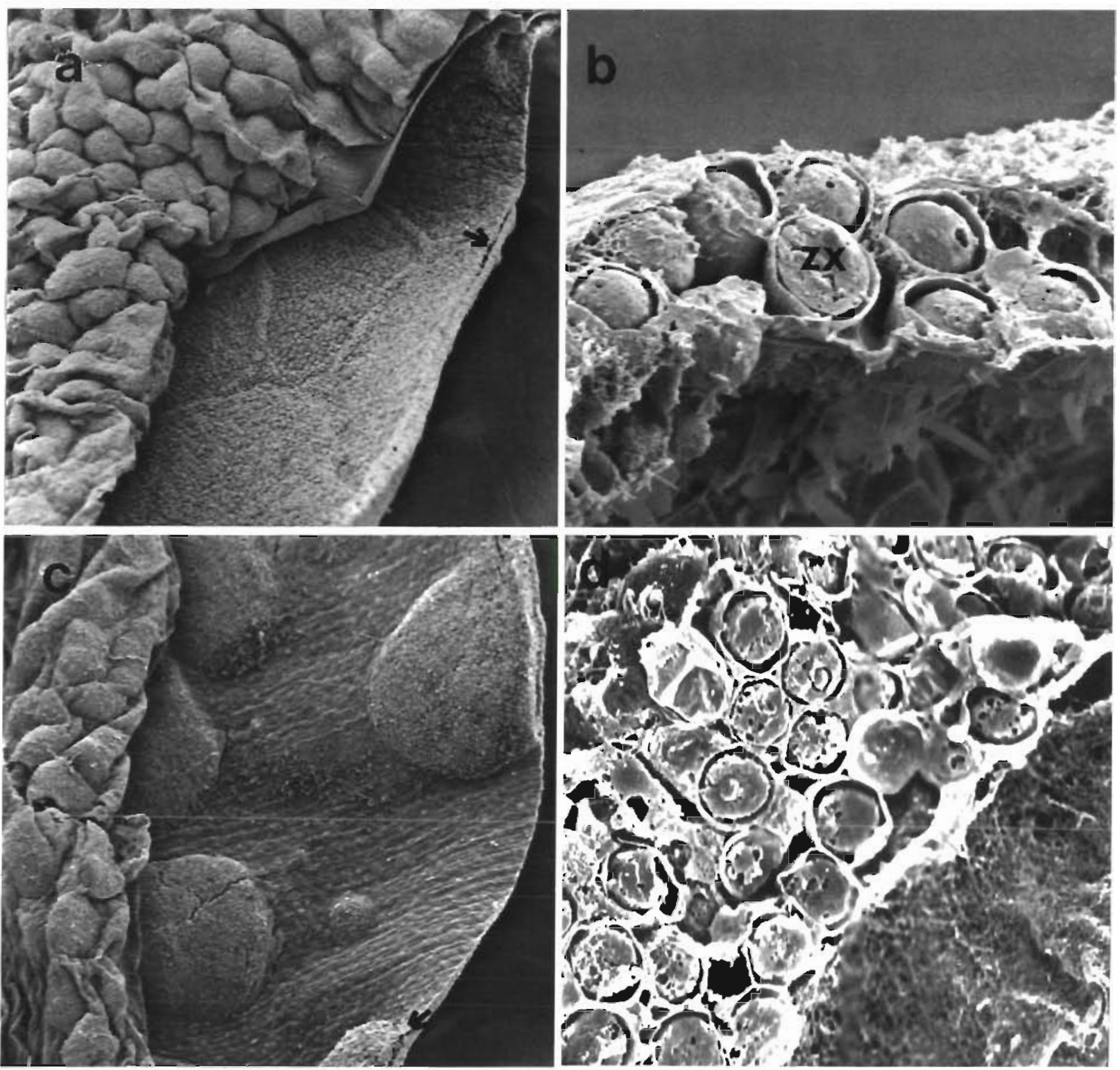

Fig. 3. Linuche unguiculata. SEM showing cyrofractured section through medusa bell. Expansion of zooxanthellae patches during daylight (a) and enlargement (arrow) of the mesogleal layer enclosing the zooxanthellae (b) Also shown are analogous pictures for dark phase medusae ( $c$ and d). Note that the zooxanthellae (ZX) layering is 1 to 2 cells thick during daylight and 4 to 5 cell thick during the contracted, night phase. $(a, c) \times 75 ;(b) \times 1600$; (d) $\times 1300$ 

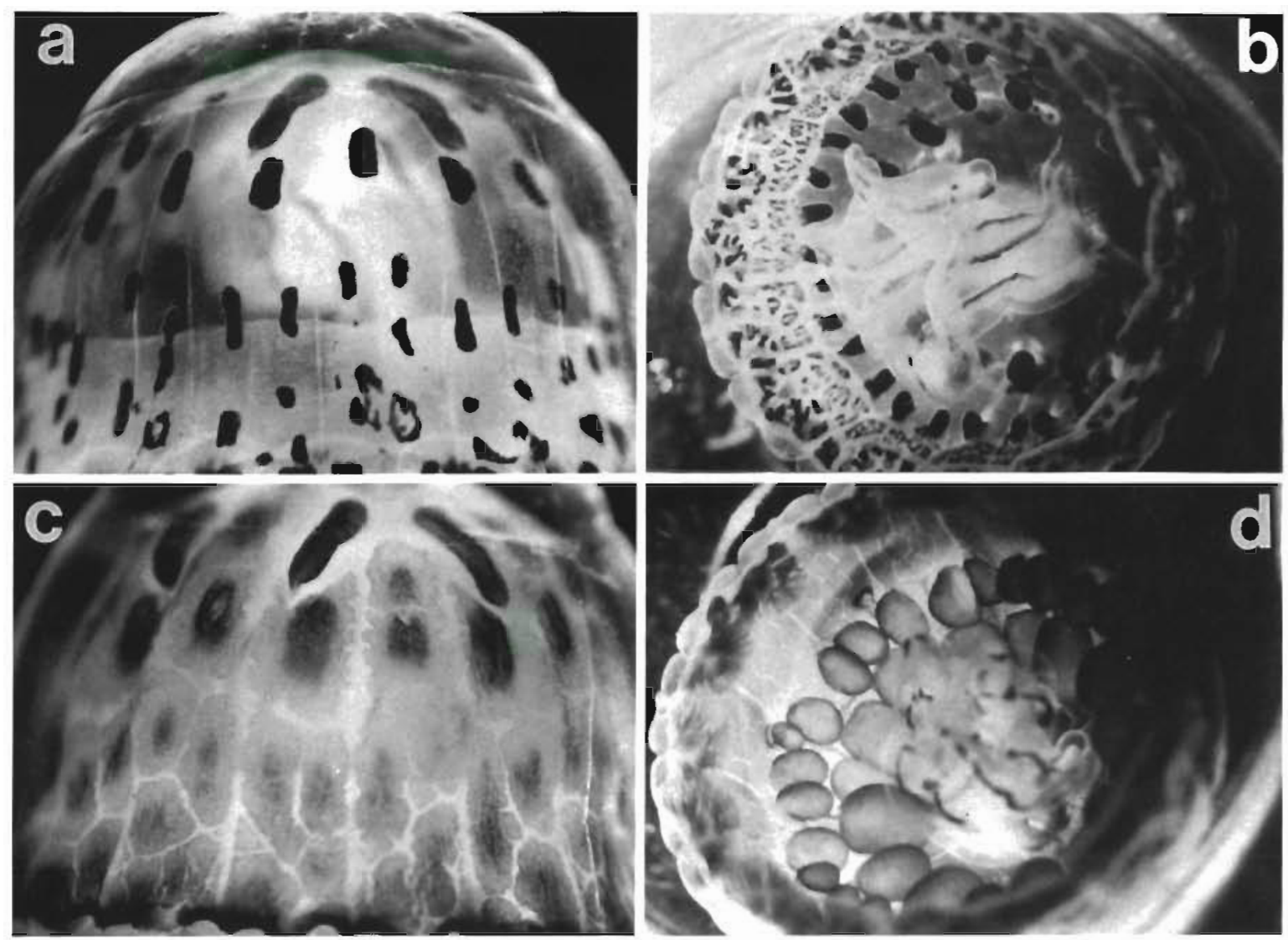

Fig. 4. Linuche unguiculata. Photographs of the same medusa dunng night $(04: 00 \mathrm{~h})$ and day $(12: 00 \mathrm{~h})$ phase. Exumbrellar and subumbrellar views are shown for both night $(a, b)$ and day $(c, d)$ phases. $a, c \times 8 ; b, d \times 6$

rhythm was greater for the controls held more than $48 \mathrm{~h}$ without any prior exposure to light. Thus, the amplitude but not the timing of the rhythm, may have been affected by handling or the brief exposure to light during the sampling process. However, variations in the amplitudes of the dark controls may also be attributed to differences in zooxanthellae patch sizes of individual medusae. These differences were significant in some cases (Fig. 6d). The dark control data demonstrate that although the sampling process may have contributed to the gradual damping of the rhythm, the photographic method did not affect the periodicity of the underlying rhythm. This is consistent with the observation that brief exposure to light at intervals of less than $6 \mathrm{~h}$ did not rephase circadian rhythmicity in Euglena gracilis (Edmunds \& Funch 1969).

\section{DISCUSSION}

\section{Location of zooxanthellae within host tissues}

In contrast to the endodermal location of most zooxanthellae in cnidarian tissues (Sebens 1987), zooxan- thellae within Linuche unguiculata appear to be located in the mesogleal cell layer. Two factors indicate that these zooxanthellae are located within mesogleal cells. First, animal cell nuclei were locited within the mesoglea in the same matrix which surrounds the zooxanthellae and, second, the zooxanthellae were surrounded by vacuole-like membranes within the mesogleal layer. These data are in agreement with the

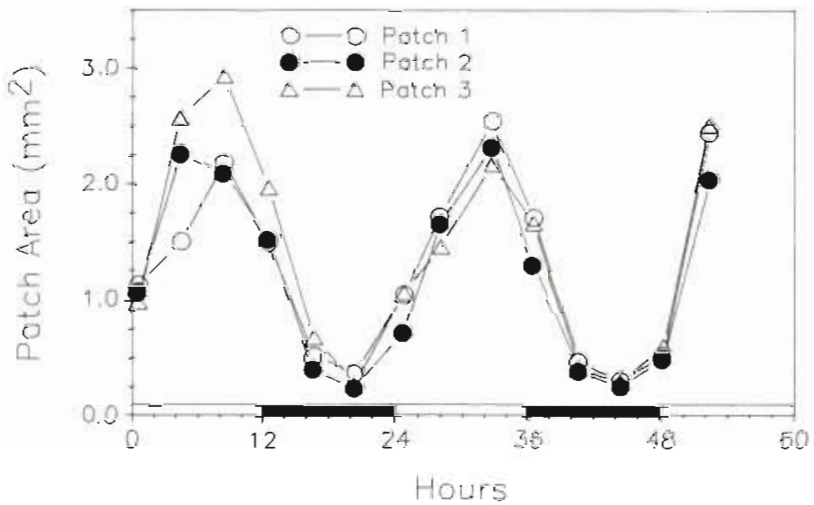

Fig. 5. Linuche unguiculata. Comparison of 3 zooxanthellae patches within a single medusa maintained on a $12 \mathrm{~h}$ light: dark cycle for $52 \mathrm{~h}$ 


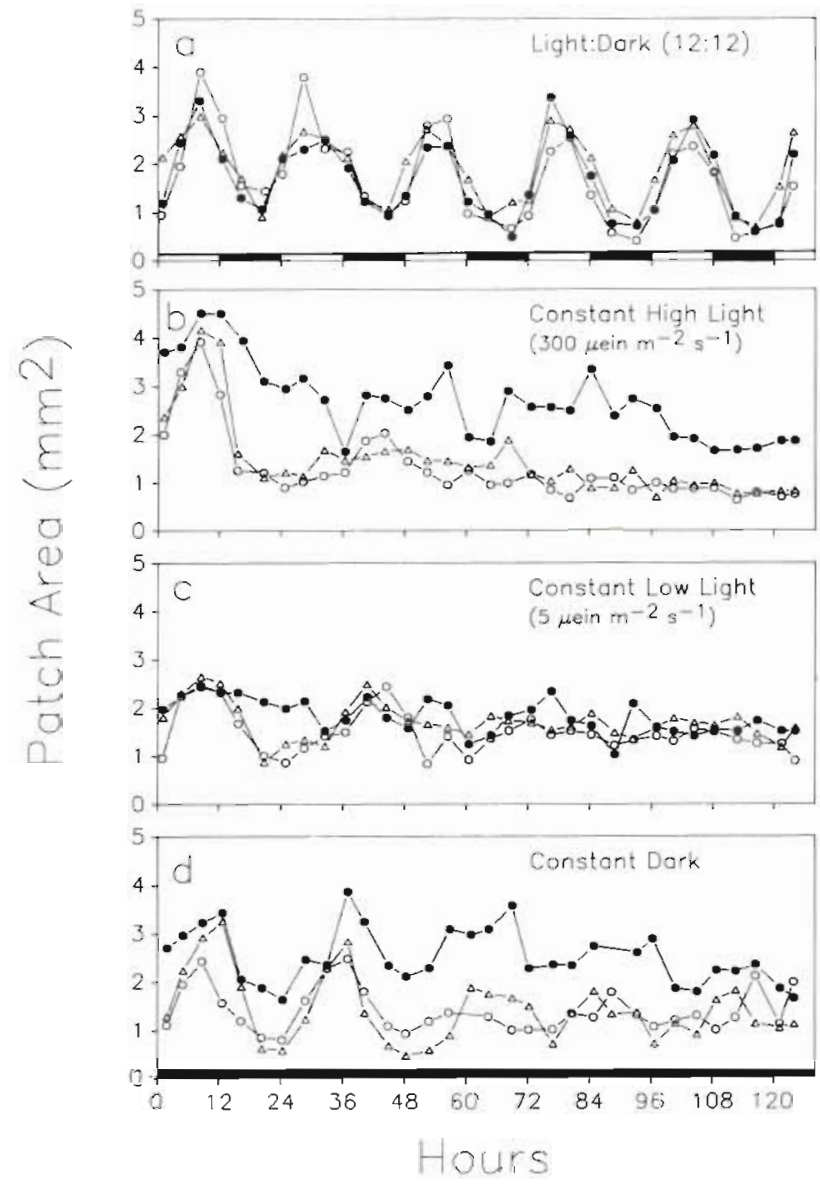

Fig. 6. Linuche unguiculata. Zooxanthellae patch area variations for medusae maintained in 4 light regimes over $5 \mathrm{~d}$. Three medusae (symbols: $0 \triangle$ ) were maintained in each light treatment (a) $12 \mathrm{~h}$ light $12 \mathrm{~h}$ dark cycle; (b) constant high light (300 $\left.4 \mathrm{E} \mathrm{m}^{-2} \mathrm{~s}^{-1}\right)$; (c) constant low light $\left(5 \mu \mathrm{E} \mathrm{m}^{-2} \mathrm{~s}^{-1}\right)$; (d) constant dark

results of Colley \& Trench (1985) demonstrating that zooxanthellae are located within vacuoles in mesogleal amoebocytes of the scyphomedusa Cassiopeia xamachana. Similar results were found for the scyphomedusa Mastigias sp. (Muscatine et al. 1986) and indicate that location of zooxantheliae within mesogleal cells is common among medusan symbioses

\section{Patch size variation}

The endogenous expansion-contraction rhythm of Linuche unguiculata zooxanthellae patches appears to be unique among cnidarian-zooxanthellae associations. Diel variations in photosynthetic organ size of anemones (Giadfelter 1975) and corals (Fricke \& Vareschi 1982) are directly cued to ambient light intensity and exhibit no endogenous rhythmicity One advantage of endogenous rhythms such as that of $L$
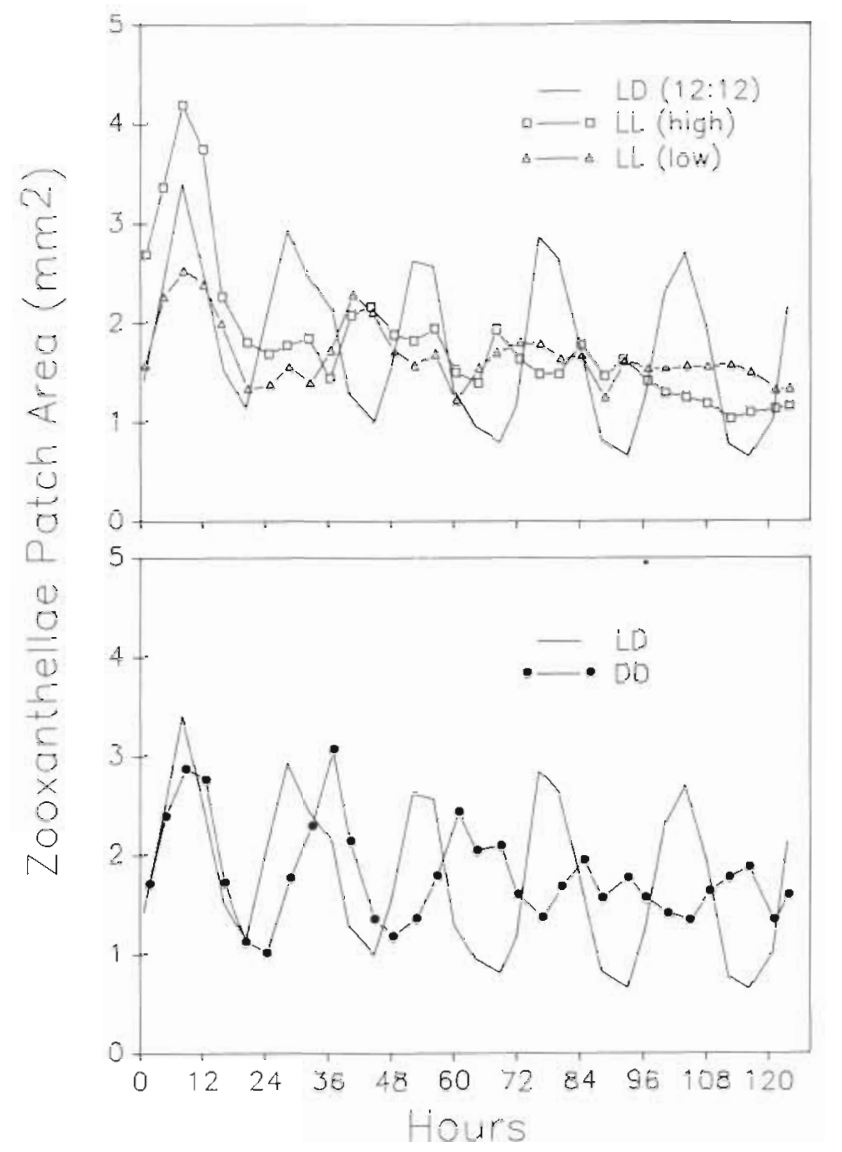

Fig. 7 Linuche unguiculata. Comparison of average zooxanthellae patch area for constant conditions versus those of light: dark regime. Upper: average zooxanthellae patch area of constant light medusae held under low $\left(5,1 \mathrm{E} \mathrm{m}^{-2} \mathrm{~s}^{-1} ; \mathrm{LL}\right)$ and high $\left(300 \mu \mathrm{E} \mathrm{m}^{-2} \mathrm{~s}^{-1}\right.$; HL) light. Lower; average zooxanthellae patch area of constant dark medusae (DD)

unguiculata, in comparison to completely exogenously cued behaviors, is that the precise timing characteristic of endogenous rhythms may synchronize the nutritional coupling of the symbiont and its host. Peak photosynthetic capacity of zooxanthellae from homogenized L. unguiculata medusae coincides with the expanded phase of the patch rhythm (Kremer et al. in press). Likewise, contraction of zooxanthellae patches in $L$. unguiculata may permit energetic savings to the symbiosis by decreasing respiration loss by zooxanthellae during dark hours. This is supported by data demonstrating that contraction of tissues decreases respiratory rates on other cnidarians (Braefield \& Chapman 1965, Lasker 1981, Sebens 1987). Timing with endogenous oscillators can allow the host and symbiont to anticipate' changes in environmental variables affecting their mutual nutrition. For example, patch expansion and contraction anticipate changes in light and dark conditions during a regular 12:12 LD cycle (Fig. 6a). 
In contrast to the independent movement of isolated zooxanthellae, expansion-contraction rhythms of Linuche unguiculata are complex and involve intracellular zooxanthellae, and therefore, host cell movement. The movement of the zooxanthellae patches within $L$. unguiculata is not consistent with descriptions of amoebocytes in scyphomedusa as 'loose' (Hyman 1940) or 'wandering' (Barnes 1974). Rather, zooxanthellae patch size variations were regular and organized. This suggests that either patch size variation in L. unguiculata is an exception to the rule or that traditional views underestimate the organization of the mesogleal layer in scyphomedusae. L. unguiculata could be a useful model for investigation of the mechanics of amoeboid movement within the mesoglea.

While the mechanism of rhythmic zooxanthellae movement in Linuche unguiculata is unknown, the control of rhythm expression may be related to $L$. unguiculata's algal symbiont. Little is presently known about this zooxanthellae because it does not appear to be of the widespread species Symbiodinium microadriaticum ( $R$. Trench pers. comm.). However, coupling between host activities and zooxanthellae rhythms is known for other cnidarian-zooxanthellae symbioses. The timing of a circadian rhythm in calcification capacity of the hermatypic coral Acropora cervicornis coincides with circadian rhythms in photosynthetic capacity and release of photosynthetically fixed carbon by the coral's zooxanthellae. Substantial transfer of organic materials from algal to host tissues occurs in cnidarian symbioses (Von Holt \& Von Holt 1968, Trench 1979) and the presence of algae has been demonstrated to affect the behavior of anemones (Pearse 1974). Further research is necessary in order to describe, in greater detail, the relationship between endogenous rhythms in host and symbiont cells. It may

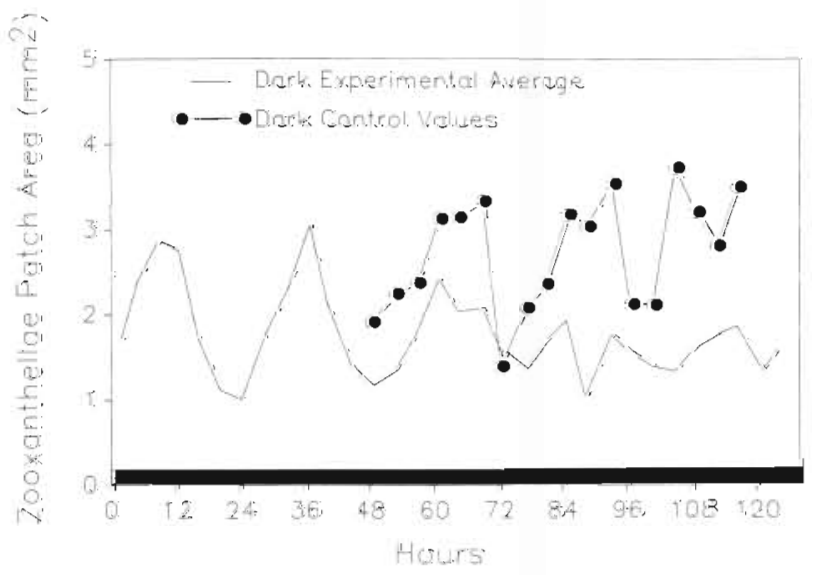

Fig. 8. Linuche unguiculata. Comparison of average zooxanthellae paich area of constant dark conditioned medusae and that of dark control medusae be that endogenous rhythms serve as timing mechanisms which synchronize the complex biochemical and behavioral adaptations of hosts, such as $L$. unguiculata, to those of their symbionts.

Acknowledgements. This is Allan Hancock Library contribution \#435. The authors thank G. Spedding for use of the digitizing equipment and programs, A. Thompson and R. Bils for assistance with microscopy, M. Reeve, M. Syms, and $M$. Canino for assistance in the field, L. Muscatine for comments on the manuscript and R. E. Pieper (OCE-841509) for financial support to JHC during periods of this work. This manuscript benefited from the comments of 3 anonymous reviewers. This research was primarily supported by NSF (OCE-8118237 to PMK) and NIH (USC Biomedical Grants to PMK and REP). Support for JHC during manuscript preparation was provided by J. R. Strickler (OCE-8719984).

\section{LITERATURE CITED}

Barnes, R. D. (1974). Invertebrate zoology, 3rd edn. W. B Saunders, Philadelphia

Braefield, A. E., Chapman, G. (1965). The oxygen consumption of Pennatula rubra Ellis and some other anthozoans. Z. vergl. Physiol. 50: 363-370

Chalker, B. E. (1977). Daily variation in the calcification capacity of Acropora cervicornis. Proc. 3rd int. Symp. coral Reefs 2: 417-424 |Taylor, D. L. (ed.) School of Marine and Atmospheric Sciences, University of Miami]

Chalker, B. E., Taylor, D. L. (1978). Rhythmic variations in calcification and photosynthesis associated with the coral Acropora cervicornis (Lamarck). Proc. R. Soc. (Ser. B.) 201. 179-189

Colley, N. J., Trench, R. K. (1985). Cellular events in the reestablishment of a symbiosis between a marine dinoflagellate and a coelenterate. Cell Tissue Res. 239: 93-103

Edmunds, L. N., Jr, Funch, J. (1969). Effects of 'skeleton' photoperiods and high frequency light-dark cycles on the rhythm of cell division in synchronized cultures of Euglena. Planta 87: 134-163

Fricke, H., Vareschi, E (1982). A scleractinian coral (Plerogyra sinuosa) with 'photosynthetic organs' Mar. Ecol. Prog. Ser 7: $273-278$

Gladfelter, W B. (1975). Sea anemone with zooxantheliae: simultaneous contraction and expansion in response to changing light intensity. Science 189:570-571

Hyman, L. H. (1940). The invertebrates: protozoa through ctenophora. McGraw-Hill, New York

Kremer, P., Costello, J. H., Canino, M. (in press). Ecological physiology of Linuche unguiculata, a scyphomedusa with symbiotic zooxanthellae. Limnol. Oceanogr.

Lasker, H. R. (1981). Phenotypic variation in the coral Montastrea cavernosa and its effects on colony energetics. Biol. Bull. mar. biol. Lab. Woods Hole 160: 292-302

Muscatine, L., Wilkerson, F. P., McCloskey, L. R. (1986). Regulation of population density of symbiotic algae in a tropical marine jellyfish (Mastigias sp.). Mar Ecol. Prog. Ser. 32: 279-290

Pearse, V B. (1974). Modification of sea anemone behavior by symbiotic zooxanthellae: expansion and contraction. Biol. Bull. mar biol. Lab., Woods Hole 147: 641-651

Sebens, K. P. (1987). Coelenterata. In: Vernberg, F. J. (ed.) Animal energetics, Vol. 1. Academic, San Diego, p. 55-125 Sebens, K. P., DeRiemer, K. (1977). Diel cycles of expansion 
and contraction in coral reef anthozoans. Mar Biol. 4: $247-256$

Trench, R. K. (1979). The cell biology of plant-animal symbiosis. A. Rev. Pl. Physiol. 30: 485-531

Vareschi, E., Fricke, H. (1986). Light response of a scler-

This article was submitted to the editor actinian coral (Plerogyra sinuosa). Mar Biol. 90: 395-402

Von Holt, C., Von Holt, M. (1968). The secretion of organic compounds by zooxanthellae isolated from various types of Zoanthus. Comp. Biochem. Physiol. 24: 83-92

Manuscript first received: January 4, 1989

Revised version accepted: July 27, 1989 